\title{
The efficiency of triazole fungicides in sugar beet protection against Cercospora beticola Sacc. depending on the plant infection at the time of the protective treatment
}

\section{Skuteczność fungicydów triazolowych w ochronie buraka cukrowego przed chwościkiem (Cercospora beticola Sacc.) w zależności od porażenia roślin w momencie wykonywania zabiegu ochronnego}

\author{
Jacek Piszczek ${ }^{1}{ }^{*}$, Dariusz Górski ${ }^{1}$, Agnieszka Ulatowska ${ }^{1}$, \\ Mirosław Nowakowski ${ }^{2}$, Wojciech Miziniak ${ }^{1}$
}

\section{Summary}

The objective of a series of strict 19 field experiments conducted in 2007-2010 was to evaluate the efficiency of triazole fungicides depending on the degree of sugar beet leaf infection by Cercospora beticola Sacc. at the time of the application. The delayed treatment resulted in a significant decrease of the effectiveness of the used fungicides. The increase of infection degree by $1.0 \%$ at the time of treatment decreased effectiveness of fungicide on average by $3.0 \%$. The infection of plants by $C$. beticola had a significant effect on the root and sugar yield.

Key words: sugar beet; Cercospora beticola; infection level; triazole fungicides; protection effectiveness

\section{Streszczenie}

Serię 19 doświadczeń polowych, których celem było określenie skuteczności fungicydów triazolowych w zależności od stopnia porażenia buraka cukrowego przez chwościka (Cercospora beticola Sacc.) w momencie wykonywania zabiegu ochronnego, przeprowadzono w latach 2007-2010. Opóźnienie zabiegów skutkowało istotnym obniżeniem skuteczności fungicydów. Wzrost stopnia porażenia roślin o 1\% powodował spadek skuteczności ochronnej stosowanych fungicydów o 3\%. Porażenie roślin przez chwościk miało istotny wpływ na plon korzeni i cukru.

Słowa kluczowe: burak cukrowy; Cercospora beticola; stopień porażenia; fungicydy triazolowe; skuteczność ochronna

\footnotetext{
Instytut Ochrony Roślin - Państwowy Instytut Badawczy

Terenowa Stacja Doświadczalna

Pigwowa 16, 87-100 Toruń

Instytut Hodowli i Aklimatyzacji Roślin - Państwowy Instytut Badawczy

Oddział w Bydgoszczy

Al. Powstańców Wielkopolskich 10, 85-090 Bydgoszcz

*corresponding author: j.piszczek@iorpib.poznan.pl
} 


\section{Wstęp / Introduction}

The increase of the threat from Cercospora beticola Sacc. on sugar beet in Poland has been observed since the 1990s. This is due to the introduction of sugar beet varieties with a low resistance to this pathogen to the polish market (Nowakowska et al. 1997; Wójtowicz and Jakubowska 2000). The changes in technology of harvesting and leaving leafs in the soil as a green manure, and reducing the use of silages leafs as fodder for cattle was also very important (Schäufele and Wevers 1996).

Currently $C$. beticola is the most devastating fungal disease of sugar beet leafs in Poland. The disease occurs annually throughout the sugar beet crop and the plant requires chemical protection. $C$. beticola under favorable conditions with hot and humid weather, may contribute to loss in yield of roots up to $50 \%$ (Bleiholder and Weltzien 1972) and significant losses in yield of sugar (Shane and Teng 1992; Rossi et al. 2000).

In practice, the observed efficiency of the fungicides is often not satisfactory. It may be due to the prevalence of resistance to fungicides fungus (Piszczek 2004; Piszczek and Czekalska 2006) but also a decrease in the effectiveness of treatment as a result of its late application (Ayala and Bermejo 2003).

The evaluation of the effectiveness of selected fungicides in controlled $C$. beticola field experiments, depending on the degree of infection of plants at the time of their application, was the aim of study.

\section{Materiały i metody / Materials and methods}

In 2007-2010, in 10 villages in the Kuyavian-Pomeranian, a series of 19 field experiments took place which examined the effectiveness of the selected triazole fungicides in controlling cercospora leaf spot, with varying degrees of leaf infection at the time of the first protective application. The study was done on ten varieties of sugar beet with a similar susceptibility to $C$. beticola (Boryna, Bruno, Carlos, Griffin, Kujawska, Leopard, Lupus, Soplica, Zawisza, Zosia).

In every experiment a control variant (without chemical protection) and a protected variant (two protective spraings) were established.

The following fungicides: Duett $250 \mathrm{SC}$ (carbendazim - $125 \mathrm{~g} / \mathrm{l}$ and epoxiconazole - $125 \mathrm{~g} / \mathrm{l}$ ), Horizon $250 \mathrm{EW}$ (tebuconazole - $250 \mathrm{~g} / \mathrm{l}$ ), Orius $250 \mathrm{EW}$ (tebuconazole $250 \mathrm{~g} / \mathrm{l}$ ) Rubric $125 \mathrm{SC}$ (epoxiconazole - $125 \mathrm{~g} / \mathrm{l}$ ) and Soprano $125 \mathrm{SC}$ (epoxiconazole - $125 \mathrm{~g} / \mathrm{l}$ ) were used for protection. The location of experiments, a variety of fungicides and doses are presented in Tables 1 and 2 .

Assessment of the plant infection by $C$. beticola was carried out in accordance with European and Mediterranean Plant Protection Organization standard (EPPO 2002). The degree of leaf infection (\%) was assessed at 5 randomly selected points of the plot by making an assessment of at least 5 adjacent plants along the row (at least 25 plants per plot in all) in 9 degrees scale. Evaluation was done on the first treatment $(\mathrm{BBCH} 39)$, and before harvest roots (BBCH 49).
Infection index (IP) was calculated according to the formula:

$$
\mathrm{IP} \%=\frac{\Sigma(\mathrm{P} \times \mathrm{W})}{\mathrm{n}}
$$

wherein: $\Sigma(\mathrm{P} \times \mathrm{W})-$ the sum of the ratios of the number of plants infested to a certain extent $-(\mathrm{P})$ by the corresponding value of the infection degree - $(\mathrm{W}), \mathrm{n}$ - total number of assessed plants.

The effectiveness of fungicides ( $\mathrm{Sk}$ ) was calculated according to the formula Henderson-Tilton:

$$
\mathrm{Sk} \%=\left(1-\frac{\mathrm{Ta}}{\mathrm{Tb}} \times \frac{\mathrm{Cb}}{\mathrm{Ca}}\right) \times 100
$$

where: $\mathrm{Cb}$ - infection index in control before spraying, $\mathrm{Ca}$ - an infection index in the control after spraying, Ta - an infection index in the variant protected after application, $\mathrm{Tb}$ - infection index in the protected variant prior to protection application.

The root yield was determined in four randomly assigned plots of $10 \mathrm{~m}^{2}$ (four rows along the length of $5.6 \mathrm{~m}$ ), and the controlled and protected variant, and converted to root mass containing $16 \%$ sugar. The sugar content of the roots was determined on an automatic Venema line.

The results of the infection index and root yield were statistically analyzed using one-way ANOVA. The significance of differences between the combinations was rated in accordance with the procedure Newman-Keuls test at the significance level $\alpha=0.05$. The relation between the index of infected plants by $C$. beticola and fungicide effectiveness, root yield and sugar content in the roots, were expressed using linear regression equations. The significance of equations was tested at $p=0.05$. The entire calculation was performed in Excel 2010, ARM 9 (Agriculture Research Manager) and STATISTICA v. 10.

\section{Wyniki i dyskusja / Results and discussion}

Chemical protection of sugar beet, regardless of the year, the place and variations led to a significant decrease of leaf infection by $C$. beticola (Tab. 1). Results of 19 experiments showed that, on average, the use of fungicides reduced the leaf infection index by the pathogen by $18.3 \%$.

Furthermore, regression analysis showed that the efficiency of the fungicide was significantly correlated with the degree of leaf infection by $C$. beticola on the day of application. On the basis of the derived regression equation (Fig. 1) it was found that the delay in protective application led to a significant increase of plant infection by $C$. beticola, and thus to a significant decrease in the effectiveness of fungicides. The increase of leaf infection by $C$. beticola caused a decrease in effectiveness of the fungicides by $3.0 \%$. Moreover, application at the time when the level of infection was close to zero provided effectiveness of the fungicides to a level of $76.8 \%$, and in the initial infection of $10 \%$, protective effectiveness decreased to $46.7 \%$. 
Tabela 1. Wpływ porażenia przez Cercospora beticola w dniu zabiegu na skuteczność fungicydu

Table 1. Effect of plant infection by Cercospora beticola at the day of application on efficacy of fungicide

\begin{tabular}{|c|c|c|c|c|c|c|c|}
\hline \multirow[b]{2}{*}{$\begin{array}{l}\text { Rok } \\
\text { Year }\end{array}$} & \multirow[b]{2}{*}{$\begin{array}{l}\text { Miejscowość } \\
\text { Location }\end{array}$} & \multirow[b]{2}{*}{$\begin{array}{l}\text { Odmiana } \\
\text { Variety }\end{array}$} & \multirow[b]{2}{*}{$\begin{array}{l}\text { Preparat } \\
\text { Treatment }\end{array}$} & \multirow[b]{2}{*}{$\begin{array}{l}\text { Dawka } \\
\text { Dose } \\
{[1 / \text { ha }]}\end{array}$} & \multicolumn{2}{|c|}{ Indeks porażenia - Disease index } & \multirow[b]{2}{*}{$\begin{array}{c}\text { Skuteczność } \\
\text { Efficacy } \\
{[\%]}\end{array}$} \\
\hline & & & & & $\begin{array}{c}\text { przy aplikacji } \\
\text { at application } \\
{[\%]}\end{array}$ & $\begin{array}{c}\text { przy zbiorze } \\
\text { at harvest } \\
{[\%]}\end{array}$ & \\
\hline \multirow{10}{*}{2007} & \multirow{2}{*}{ Piwnice } & \multirow{2}{*}{ Kujawska } & kontrola - control & - & $2,7 \mathrm{a}$ & $19,4 \mathrm{a}$ & - \\
\hline & & & Duett $250 \mathrm{SC}$ & 1,00 & $2,8 \mathrm{a}$ & $8,8 \mathrm{~b}$ & 55,5 \\
\hline & \multirow{2}{*}{ Sierzchowo } & \multirow{2}{*}{ Zawisza } & kontrola - control & - & $17,8 \mathrm{a}$ & $45,5 \mathrm{a}$ & - \\
\hline & & & Orius $250 \mathrm{EW}$ & 0,80 & $13,1 \mathrm{a}$ & $34,5 \mathrm{~b}$ & $-3,0$ \\
\hline & \multirow{2}{*}{ Kryńsk } & \multirow{2}{*}{ Boryna } & kontrola - control & - & $16,4 \mathrm{a}$ & $55,1 \mathrm{a}$ & - \\
\hline & & & Soprano $125 \mathrm{SC}$ & 1,00 & $16,9 \mathrm{a}$ & $27,6 \mathrm{~b}$ & 51,6 \\
\hline & \multirow{2}{*}{ Falęcin } & \multirow{2}{*}{ Lupus } & kontrola - control & - & $6,1 \mathrm{a}$ & $29,3 \mathrm{a}$ & - \\
\hline & & & Duett 250 SC & 1,00 & $6,9 \mathrm{a}$ & $17,9 \mathrm{~b}$ & 45,6 \\
\hline & \multirow{2}{*}{ Koniczynka } & \multirow{2}{*}{ Zawisza } & kontrola - control & - & $1,1 \mathrm{a}$ & $25,4 \mathrm{a}$ & - \\
\hline & & & Duett $250 \mathrm{SC}$ & 1,00 & $1,4 \mathrm{a}$ & $14,4 \mathrm{~b}$ & 53,6 \\
\hline \multirow{10}{*}{2008} & \multirow{2}{*}{ Sierzchowo } & \multirow{2}{*}{ Kujawska } & kontrola - control & - & $6,3 \mathrm{a}$ & $22,6 \mathrm{a}$ & - \\
\hline & & & Duett $250 \mathrm{SC}$ & 1,00 & $5,9 \mathrm{a}$ & $13,0 \mathrm{~b}$ & 38,7 \\
\hline & \multirow{2}{*}{ Grzybno } & \multirow{2}{*}{ Gryf } & kontrola - control & - & $5,3 \mathrm{a}$ & 33,9 a & - \\
\hline & & & Orius $250 \mathrm{EW}$ & 0,80 & $4,6 \mathrm{a}$ & $25,3 \mathrm{~b}$ & 15,4 \\
\hline & \multirow{2}{*}{ Kryńsk } & 7ашісла & kontrola - control & - & $15,8 \mathrm{a}$ & $55,9 \mathrm{a}$ & - \\
\hline & & ZaWIsZa & Duett 250 SC & 1,00 & $15,8 \mathrm{a}$ & $23,0 \mathrm{~b}$ & 58,8 \\
\hline & Koniczunle & I & kontrola - control & - & $6,5 \mathrm{a}$ & $34,4 \mathrm{a}$ & - \\
\hline & АОПпС Супка & Lupus & Duett 250 SC & 1,00 & $7,1 \mathrm{a}$ & $12,4 \mathrm{~b}$ & 67,2 \\
\hline & Jolonies & J eopord & kontrola - control & - & $0,3 \mathrm{a}$ & $44,8 \mathrm{a}$ & - \\
\hline & 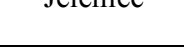 & Leopara & Rubric $125 \mathrm{SC}$ & 1,00 & $0,1 \mathrm{~b}$ & $0,3 \mathrm{~b}$ & 98,3 \\
\hline & Koniczynk & Sonlico & kontrola - control & - & $0,2 \mathrm{a}$ & $26,5 \mathrm{a}$ & - \\
\hline & АОпгодупка & sopilca & Horizon 250 EW & 0,80 & $0,1 \mathrm{a}$ & $6,0 \mathrm{~b}$ & 75,5 \\
\hline & Tylice & Zosia & kontrola - control & - & $0,1 \mathrm{a}$ & $13,6 \mathrm{a}$ & - \\
\hline & 1 уाісе & Zusla & Horizon 250 EW & 0,80 & $0,1 \mathrm{a}$ & $3,5 \mathrm{~b}$ & 68,2 \\
\hline 2000 & Tytlewe & Brung & kontrola - control & - & $0,1 \mathrm{a}$ & $10,4 \mathrm{a}$ & - \\
\hline 2007 & 1 уето & Б1 unv & Horizon $250 \mathrm{EW}$ & 0,80 & $0,1 \mathrm{a}$ & $0,5 \mathrm{~b}$ & 95,1 \\
\hline & Dinunis & Corlor & kontrola - control & - & $0,1 \mathrm{a}$ & $12,4 \mathrm{a}$ & - \\
\hline & PIWIIICE & Callos & Horizon 250 EW & 0,80 & $0,0 \mathrm{a}$ & $1,1 \mathrm{~b}$ & 83,4 \\
\hline & I inniçli & Boryna & kontrola - control & - & $0,4 \mathrm{a}$ & $17,9 \mathrm{a}$ & - \\
\hline & Lірпाс & Dолупа & Horizon 250 EW & 0,80 & $0,8 \mathrm{a}$ & $5,0 \mathrm{~b}$ & 85,7 \\
\hline & Koniczynka & Sonlica & kontrola - control & - & $0,2 \mathrm{a}$ & $27,8 \mathrm{a}$ & - \\
\hline & 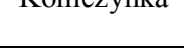 & Soppila & Horizon $250 \mathrm{EW}$ & 0,80 & $0,2 \mathrm{a}$ & $3,3 \mathrm{~b}$ & 89,7 \\
\hline & Tylice & $70 \operatorname{sia}$ & kontrola - control & - & $0,1 \mathrm{a}$ & $26,5 \mathrm{a}$ & - \\
\hline 2010 & 1 упеट & Zusida & Horizon 250 EW & 0,80 & $0,0 \mathrm{~b}$ & $3,7 \mathrm{~b}$ & 71,6 \\
\hline & Tytlewo & Bruno & kontrola - control & - & $0,1 \mathrm{a}$ & 7,9 a & - \\
\hline & & & Horizon $250 \mathrm{EW}$ & 0,80 & $0,1 \mathrm{a}$ & $1,0 \mathrm{~b}$ & 90,0 \\
\hline & Jelenier & J eonard & kontrola - control & - & $0,3 \mathrm{a}$ & $45,0 \mathrm{a}$ & - \\
\hline & Jefinte & Leopard & Soprano $125 \mathrm{SC}$ & 1,00 & $0,3 \mathrm{a}$ & $6,0 \mathrm{~b}$ & 88,8 \\
\hline $2007-2010$ & - & - & kontrola - control & - & 4,2 & 29,2 & - \\
\hline $2007-2010$ & - & - & ochrona - protection & - & 4,0 & 10,9 & 64,7 \\
\hline
\end{tabular}

Średnie wartości dla preparatów w miejscowościach oznaczone tą samą literą nie różnią się istotnie zgodnie z regułą Fishera przy p < 0,05

Means for treatments in locations marked by the same letter do not differ significantly according to Fisher's test at $\mathrm{p}<0.05$ 
Tabela 2. Wpływ fungicydu na plon korzeni i zawartość cukru w korzeniach

Table 2. Effect of fungicide on the root yield and sugar content in the roots

\begin{tabular}{|c|c|c|c|c|c|c|c|c|}
\hline \multirow{2}{*}{$\begin{array}{l}\text { Rok } \\
\text { Year }\end{array}$} & \multirow{2}{*}{$\begin{array}{l}\text { Miejscowość } \\
\text { Location }\end{array}$} & \multirow{2}{*}{$\begin{array}{l}\text { Odmiana } \\
\text { Variety }\end{array}$} & \multirow{2}{*}{$\begin{array}{l}\text { Preparat } \\
\text { Treatment }\end{array}$} & \multirow{2}{*}{$\begin{array}{c}\text { Dawka } \\
\text { Dose } \\
{[1 / \text { ha }]}\end{array}$} & \multicolumn{2}{|c|}{$\begin{array}{l}\text { Plon korzeni } \\
\text { Root yield }\end{array}$} & \multicolumn{2}{|c|}{$\begin{array}{l}\text { Zawartość cukru } \\
\text { Sugar content }\end{array}$} \\
\hline & & & & & {$[\mathrm{t} / \mathrm{ha}]$} & {$[\%]^{*}$} & {$[\%]$} & {$[\%]^{* *}$} \\
\hline \multirow{10}{*}{2007} & \multirow{2}{*}{ Piwnice } & \multirow{2}{*}{ Kujawska } & kontrola - control & - & $71,5 \mathrm{a}$ & - & 16,56 & \\
\hline & & & Duett $250 \mathrm{SC}$ & 1,00 & $71,0 \mathrm{a}$ & 99,3 & 16,47 & $-0,09$ \\
\hline & \multirow{2}{*}{ Sierzchowo } & \multirow{2}{*}{ Zawisza } & kontrola - control & - & $73,5 \mathrm{~b}$ & - & 15,81 & \\
\hline & & & Orius $250 \mathrm{EW}$ & 0,80 & $80,2 \mathrm{a}$ & 109,1 & 16,74 & 0,93 \\
\hline & \multirow{2}{*}{ Kryńsk } & \multirow{2}{*}{ Boryna } & kontrola - control & - & $74,4 \mathrm{a}$ & - & 16,74 & \\
\hline & & & Soprano $125 \mathrm{SC}$ & 1,00 & $83,2 \mathrm{a}$ & 111,9 & 17,89 & 1,15 \\
\hline & \multirow{2}{*}{ Falęcin } & \multirow{2}{*}{ Lupus } & kontrola - control & - & $79,7 \mathrm{~b}$ & - & 16,59 & \\
\hline & & & Duett $250 \mathrm{SC}$ & 1,00 & $94,4 \mathrm{a}$ & 118,5 & 17,47 & 0,88 \\
\hline & \multirow{2}{*}{ Koniczynka } & \multirow{2}{*}{ Zawisza } & kontrola - control & - & $84,6 \mathrm{a}$ & - & 17,17 & \\
\hline & & & Duett $250 \mathrm{SC}$ & 1,00 & $91,5 \mathrm{a}$ & 108,2 & 16,58 & $-0,59$ \\
\hline \multirow{10}{*}{2008} & \multirow{2}{*}{ Sierzchowo } & \multirow{2}{*}{ Kujawska } & kontrola - control & - & $78,0 \mathrm{a}$ & - & 16,55 & \\
\hline & & & Duett $250 \mathrm{SC}$ & 1,00 & $77,6 \mathrm{a}$ & 99,4 & 16,61 & 0,06 \\
\hline & \multirow{2}{*}{ Grzybno } & \multirow{2}{*}{ Gryf } & kontrola - control & - & $88,0 \mathrm{a}$ & - & 17,99 & \\
\hline & & & Orius $250 \mathrm{EW}$ & 0,80 & $95,5 \mathrm{a}$ & 108,5 & 18,36 & 0,37 \\
\hline & \multirow{2}{*}{ Kryńsk } & 7 urisa & kontrola - control & - & $77,0 \mathrm{a}$ & - & 16,13 & \\
\hline & & ZâISZa & Duett $250 \mathrm{SC}$ & 1,00 & $83,8 \mathrm{a}$ & 108,9 & 16,51 & 0,38 \\
\hline & $V^{\prime}$ & $T$ & kontrola - control & - & $86,6 \mathrm{~b}$ & - & 18,27 & \\
\hline & КОптеупка & Lupus & Duett 250 SC & 1,00 & $95,3 \mathrm{a}$ & 110,1 & 19,21 & 0,94 \\
\hline & Iolonis & I onond & kontrola - control & - & $66,1 \mathrm{~b}$ & - & 16,99 & \\
\hline & Jerentec & Leopara & Rubric $125 \mathrm{SC}$ & 1,00 & $78,2 \mathrm{a}$ & 118,3 & 17,16 & 0,17 \\
\hline & Koniczunk & Sonlico & kontrola - control & - & $78,4 \mathrm{a}$ & - & 17,05 & \\
\hline & КОптеупка & Soppired & Horizon 250 EW & 0,80 & $79,5 \mathrm{a}$ & 101,4 & 17,37 & 0,32 \\
\hline & Tours & 70 . & kontrola - control & - & $79,3 \mathrm{~b}$ & - & 17,20 & \\
\hline & 1ylice & Zosia & Horizon $250 \mathrm{EW}$ & 0,80 & $89,9 \mathrm{a}$ & 113,3 & 18,17 & 0,97 \\
\hline (2000 & Tutlawn & Prune & kontrola - control & - & $92,2 \mathrm{a}$ & - & 19,82 & \\
\hline & 1 уенष & Dicus & Horizon 250 EW & 0,80 & $96,0 \mathrm{a}$ & 104,1 & 20,26 & 0,44 \\
\hline & D.. & $\mathrm{C}_{1}$ & kontrola - control & - & $88,7 \mathrm{a}$ & - & 17,50 & \\
\hline & Piwnice & Carlos & Horizon $250 \mathrm{EW}$ & 0,80 & $96,8 \mathrm{a}$ & 109,2 & 17,81 & 0,31 \\
\hline & I inniczli & Roryn & kontrola - control & - & $90,5 \mathrm{a}$ & - & 16,59 & \\
\hline & LIрпICZKI & Doryna & Horizon 250 EW & 0,80 & $91,6 \mathrm{a}$ & 101,2 & 16,42 & $-0,17$ \\
\hline & Koni & Sonlino & kontrola - control & - & $76,2 \mathrm{a}$ & - & 17,02 & \\
\hline & АӦгеуУКка & sopiled & Horizon 250 EW & 0,80 & $78,8 \mathrm{a}$ & 103,4 & 17,70 & 0,68 \\
\hline & Tylico & 7ocio & kontrola - control & - & 85,9 a & - & 17,76 & \\
\hline - & 1упсе & Zosia & Horizon $250 \mathrm{EW}$ & 0,80 & $89,3 \mathrm{a}$ & 104,0 & 17,08 & $-0,68$ \\
\hline 2010 & Tutlowo & Proms & kontrola - control & - & $102,7 \mathrm{a}$ & - & 19,84 & \\
\hline & 1унтешо & Bruno & Horizon $250 \mathrm{EW}$ & 0,80 & $104,0 \mathrm{a}$ & 101,3 & 19,58 & $-0,26$ \\
\hline & Jolonio & I onond & kontrola - control & - & $61,5 \mathrm{~b}$ & - & 16,26 & \\
\hline & Jerentec & Leopara & Soprano $125 \mathrm{SC}$ & 1,00 & $75,9 \mathrm{a}$ & 123,4 & 17,31 & 1,05 \\
\hline $2007-2010$ & - & - & kontrola - control & - & 80,8 & - & 17,29 & \\
\hline & - & - & ochrona - protection & - & 87,0 & 107,8 & 17,62 & 0,33 \\
\hline
\end{tabular}

${ }^{*}$ plon korzeni w stosunku do kontroli $=100 \%$ - root yield relative to control $=100 \%$

${ }^{* *}$ wzrost zawartości cukru w punktach procentowych w stosunku do kontroli - increase of sugar content in percentage points in the root relative to control Średnie dla zabiegów w danych lokalizacjach oznaczone tą samą literą wskazują na brak różnic istotnych pomiędzy obiektami wyliczone zgodnie z regułą Fishera przy $\mathrm{p}<0,05$

Means for treatments in locations marked by the same letter do not differ significantly according to Fisher's test at $\mathrm{p}<0.05$ 


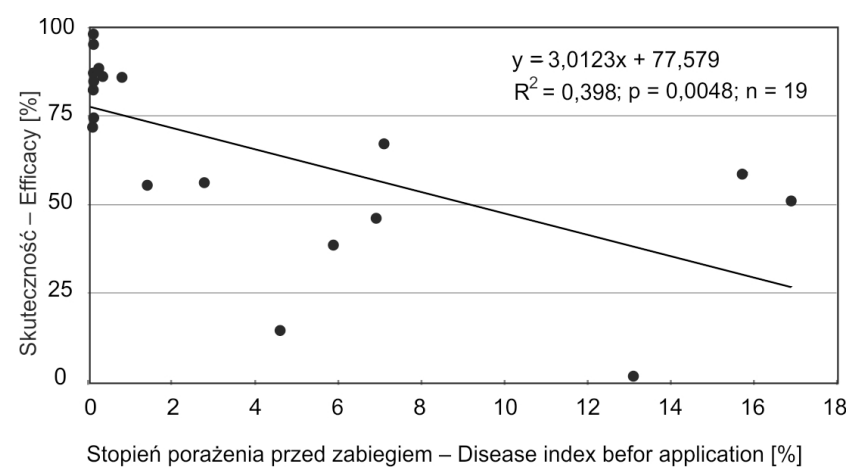

Rys. 1. Wpływ porażenia roślin przez Cercospora beticola w dniu wykonania zabiegu na skuteczność fungicydów

Fig. 1. Effect of plant infection by Cercospora beticola at the day of application on efficiency of fungicide

Chemical protection against $C$. beticola, when the degree of leaf infection by the pathogen was reduced, had positive impact on the growth of root yield and the sugar content in them. At the same time, a significant increase, compared to the unprotected variant, was found in 6 of the 19 conducted experiments (Tab. 2). Taking the average of all results, chemical protection against $C$. beticola, had an impact on the increase in root yield of $7.7 \%$, while the sugar content increased by $0.36 \%$.

In the regression equations derived (Fig. 2, 3), that the delay of application against $C$. beticola resulted in a significant decrease in sugar beet root yield and the content of sugar in them. With the increase in the leaf infection index for every $10 \%$ root yield had drop an average of $3.3 \mathrm{t} / \mathrm{ha}$ and sugar content of $0.3 \%$.

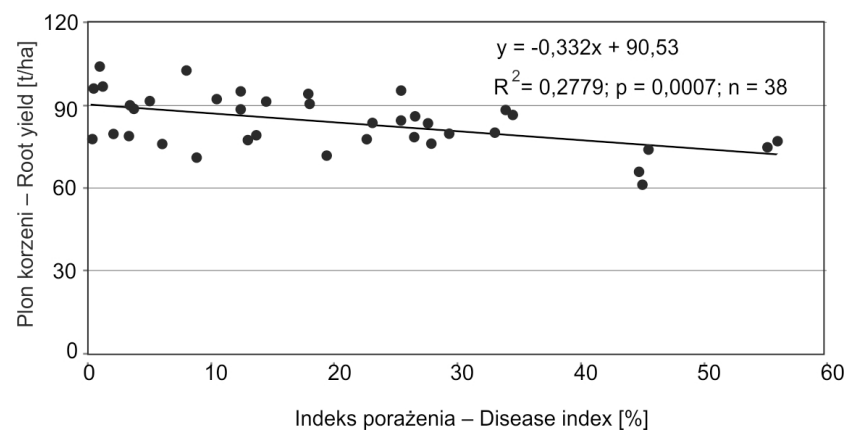

Rys. 2. Wpływ porażenia roślin przez Cercospora beticola na plon korzeni

Fig. 2. Effect of plant infection by Cercospora beticola on the root yield

The obtained results in this study correlate with the results of other authors (Anesiadis et al. 2003; Piszczek 2010). According to these studies, the highest fungicide effectiveness was obtained when chemical application was carried out just before, or within 24-48 hours post leave infection by the pathogen. Harveson and Blehm (2003) achieved a significant increase in root yield, as compared to two weeks delayed application, using chemical

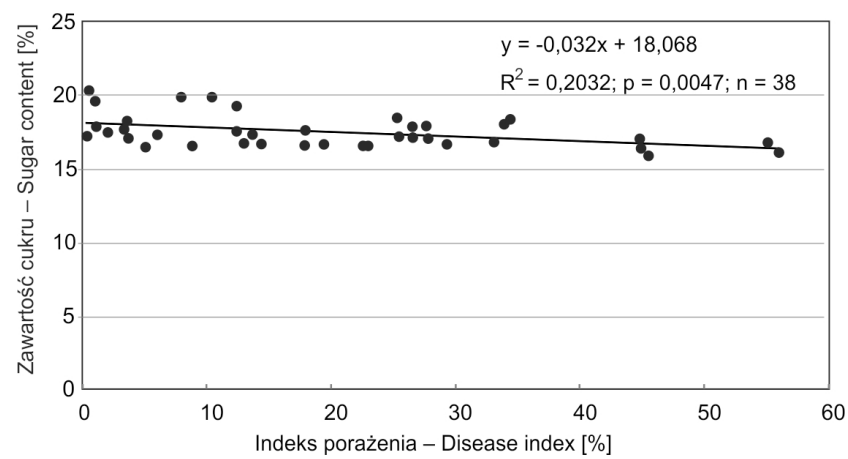

Rys. 3. Wpływ porażenia roślin przez Cercospora beticola na zawartość cukru w korzeniach

Fig. 3. Effect of plant infection by Cercospora beticola on sugar content in the roots

protection prior to the onset of the first symptoms of the disease. However, they obtained such results only with very strong disease pressure. In addition, Ayala and Bermejo (2003) compared the effectiveness of fungicides applied on sugar beet, affected to varying degrees by $C$. beticola, at the time of application. They found a decrease in the effectiveness of applications with leafs infested by the pathogen to a higher degree, compared to healthy one. The delay of application also had an impact on the resulting yield of sugar. Reaction to the application of protection depended on the used fungicide and beet variety. Merrigi et al. (2003) underline the necessity to make protective application on varieties susceptible to $C$. beticola when the first symptoms appear on leafs. Only in this case protection will be effective. The achieved results fully confirm these results. The results clearly show that, in the case of crops of varieties susceptible to $C$. beticola, with increasing leaf infection by the fungus, the efficiency of the fungicides containing the active substance from the group of triazoles declines.

\section{Wnioski / Conclusions}

1. Delayed sugar beet treatment against cercospora leaf spot resulted in a significant decrease of the effectiveness of the used fungicides.

2. The degree of infection of plants by cercospora leaf spot had a significant effect on root and sugar yield.

\section{Literatura / References}

Anesiadis T., Karaoglanidis G.S., Tzavella-Klonari K. 2003. Protective, curative and eradicant activity of the strobilurin fungicide azoxystrobin against Cercospora beticola and Erysiphe betae. Journal of Phytopathology 151 (11-12): 647-651. DOI: 10.1046/ /j.1439-0434.2003.00780.x.

Ayala J., Bermejo J.L. 2003. Control of Cercospora beticola by combination of fungicides with double tolerant cultivars (rhizomania and cercospora). p. 351-365. In: 1st joint IIRB-ASSBT Congress. San Antonio, USA, 26th February-1st March 2003,956 pp. 
Bleiholder H., Weltzien H.C. 1972. Contributions to the epidemiology of Cercospora beticola on sugar beet. III. Geopathological studies. Journal of Phytopathology 73: 99-114.

European and Mediterranean Plant Protection Organization (EPPO). 2002. Efficacy evaluation of fungicides. Foliar diseases on sugarbeet. PP 1/1(4): 1-5.

Harveson R.M., Blehm E.S. 2003. Comparing protectant and systemic fungicides using different application timings for management of Cercospora beticola leaf spot in the Nebraska Panhandle. p. 871-875. In: 1st joint IIRB-ASSBT Congress. San Antonio, USA, 26th February-1st March 2003, 956 pp.

Meriggi P., Rossi V., Paganini U. 2003. Cercospora leaf spot: integrated control in northern Italy. p. 333-346. 1st joint IIRB-ASSBT Congress. San Antonio, USA, 26th February-1st March 2003, 956 pp.

Nowakowska H., Piszczek J., Włodarski J. 1997. Porażenie odmian buraka cukrowego przez Cercospora beticola w 1995 i 1996 roku w różnych rejonach uprawy. [Infection of sugar beet varieties by Cercospora beticola in different regions of Poland in 1995 and 1996]. Progress in Plant Protection/Postępy w Ochronie Roślin 37 (2): 340-342.

Piszczek J. 2004. Odporność niektórych szczepów Cercospora beticola Sacc. na fungicydy stosowane w ochronie buraka cukrowego. [Resistance of selected strains of Cercospora beticola Sacc. to fungicides used for sugar beet protection in Poland]. Progress in Plant Protection/Postępy w Ochronie Roślin 44 (2): 1028-1031.

Piszczek J. 2010. Epidemiologia chwościka buraka cukrowego (Cercospora beticola) w centralnej Polsce. Rozprawy Naukowe. Instytut Ochrony Roślin - Państwowy Instytut Badawczy, Zeszyt 23, 70 ss.

Piszczek J., Czekalska A. 2006. Oporność chwościka buraka - grzyba Cercospora beticola Sacc. na fungicydy stosowane do jego zwalczania w Polsce. [Resistance of Cercospora beticola Sacc. to fungicides used against this pathogen in Poland]. Progress in Plant Protection/Postępy w Ochronie Roślin 46 (1): 375-379.

Rossi V., Battilani P., Chiusa G., Giosuè S., Languasco L., Racca P. 2000. Components of rate-reducing resistance to Cercospora leaf spot in sugar beet: conidiation length, spore yield. Journal of Plant Pathology 82 (2): 125-131. DOI: http://dx.doi.org/ /10.4454/jpp.v82i2.1152.

Schäufele W.R., Wevers J.D.A. 1996. Possible contribution of tolerant and partly resistant sugar beet varieties to the control of the foliar disease Cercospora beticola. p. 19-32. In: Proceedings of 60th IIRB Congress. Cambridge, UK, 1-3 July 1997, 605 pp.

Shane W.W., Teng P.S. 1992. Impact of Cercospora leaf spot on root weight, sugar yield, and purity of Beta vulgaris. Plant Disease 76 (8): 812-820.

Wójtowicz A., Jakubowska M. 2000. Wysteppowanie chorób i szkodników w uprawach buraka cukrowego w Polsce na przestrzeni ostatnich lat. [Occurrence of pests and diseases in sugar beet crops in Poland in the years 1990-1998]. Progress in Plant Protection/Postępy w Ochronie Roślin 40 (2): 442-446. 